\title{
Novel Functional Whey-Based Drinks with Great Potential in the Dairy Industry
}

\author{
Carlos Pereira ${ }^{1}$, Marta Henriques ${ }^{1 *}$, David Gomes ${ }^{1}$, Andrea Gomez-Zavaglia ${ }^{2}$ and \\ Graciela de Antoni ${ }^{2,3}$ \\ ${ }^{1}$ IPC-ESAC/CERNAS, Polytechnic Institute of Coimbra, College of Agriculture, \\ PT-3045-601 Bencanta, Coimbra, Portugal \\ ${ }^{2}$ Center for Research and Development in Food Cryotechnology, CIDCA CCT CONICET, \\ RA-1900 La Plata, Argentina \\ ${ }^{3}$ Laboratory for Microbiology, Department of Biological Sciences, Faculty of Exact Sciences, \\ UNLP, RA-1900 La Plata, Argentina \\ Received: December 22, 2014 \\ Accepted: May 13, 2015
}

\begin{abstract}
Summary
This work focuses on the production of liquid whey protein concentrates by ultrafiltration followed by thermal denaturation and homogenization of the ultrafiltrated concentrate, as well as on the production of ultrafiltrated permeates concentrated by reverse osmosis. Kefir grains (fresh and thawed) and/or commercial probiotic bacteria were inoculated in both liquid whey protein concentrates and concentrated ultrafiltrated permeates and grown at $25^{\circ} \mathrm{C}$ for $24 \mathrm{~h}$ for the manufacture of fermented drinks. The physicochemical characterization ( $\mathrm{pH}$, titratable acidity, viscosity, and content of total solids, ash, fat and proteins) of the obtained drinks was then assessed and compared. Enumeration of viable microorganisms was carried out immediately after inoculation (at $0 \mathrm{~h}$ ), during the fermentation period (at 12 and $24 \mathrm{~h}$ ) and during refrigerated storage (at 48, 168 and $336 \mathrm{~h}$ ). The fermented drinks showed acceptable physicochemical and sensorial properties, and contained above $7 \log \mathrm{CFU} / \mathrm{mL}$ of lactococci and lactobacilli and $6 \log \mathrm{CFU} / \mathrm{mL}$ of yeasts after 14 days of refrigerated storage, which is in agreement with the standards required by international organizations like European Food Safety Authority (EFSA) and Food and Drug Administration (FDA) for products containing probiotics. In summary, the strategy developed in this work contributes to the expansion of the applications of products derived from whey fractionation for the design of novel functional foods.
\end{abstract}

Key words: whey protein concentrate, ultrafiltration permeate, reverse osmosis, kefir, probiotic

\section{Introduction}

About $33 \%$ of the milk production worldwide is used in cheese manufacture, averaging about $19 \cdot 10^{6}$ tonnes per year (1). Whey is a by-product obtained during the production of cheese that can cause environmental contamination. It is basically composed of lactose and proteins of high biological value. Because of their nutri- tional importance, whey powder, whey proteins and whey protein fractions represent a global market value of approx. 6.3 billion euros (2). However, the industrial production of whey powder, whey protein concentrates, whey protein isolates, microparticulated whey proteins or polymerized whey proteins normally involves a final drying step, generally carried out by spray drying. The 
application of this operation is usually limited to large dairy industries. In small and medium scale cheese plants, the volume of whey to be processed does not justify the costs associated with the installation of such equipment. For these plants, whey disposal represents a major problem and, in most cases, a high operational cost. For this reason, the development of novel strategies that avoid the spray drying step contributes to the value of this by-product in small and medium industries.

A group of novel products obtained from whey proteins has been developed in the last years aiming to replace fats in food. These products include the use of microparticulated whey proteins manufactured from whey protein concentrates in a process involving heating and shearing $(3,4)$, or the thermal denaturation of polymerized whey proteins to obtain soluble whey protein that does not aggregate because of the absence of salts (5-7). The use of $\beta$-lactoglobulin and whey protein isolate aggregates to obtain cold-set gels, foams and emulsions, encapsulation and films/coatings has recently been reviewed (8).

In general, whey proteins are used in the form of dry whey proteins, whey protein concentrates, microparticulated whey proteins or polymerized whey proteins (9-12) as ingredients in mixtures for yoghurt production. The production and direct incorporation of liquid whey protein concentrates in food products is seldom reported. Recently, liquid whey protein concentrates have been successfully produced by ultrafiltration, and then incorporated into fresh cheese and set yoghurt $(13,14)$, providing a solution for the immediate reutilization of whey and avoiding evaporation and drying. However, the use of liquid whey protein concentrates as a substrate for the fermentation of probiotic bacteria provides an extra added value and has never been addressed.

Kefir grains include up to 400 different species of probiotic bacteria and yeasts and are able to grow in whey permeate (15). Several beneficial health effects have been ascribed to kefir, namely modulation of the immune response as well as the antibacterial and antifungal activities, among others (16-20).

The present approach envisages the utilization of liquid whey protein concentrates or ultrafiltrated permeate concentrated by reverse osmosis as substrates for the production of fermented drinks. To this aim, liquid whey protein concentrates and concentrated ultrafiltrated permeates were fermented with: $(i)$ well characterized kefir grains (16) containing microorganisms with inhibitory properties against pathogenic bacteria (17-19) or parasites (20), (ii) a commercial mix of probiotic bacteria and, (iii) their mixture, in order to obtain novel fermented dairy products.

\section{Materials and Methods}

\section{Liquid whey protein concentrate and concentrated ultrafiltrated permeate production}

Cheese whey was obtained immediately after the production of semi-hard bovine cheese at the pilot plant of Escola Superior Agrária de Coimbra (ESAC, Coimbra,
Portugal). Cheese coagulation (45 $\mathrm{min}$ ) was performed in the presence of $0.04 \%$ (by mass per volume) of $\mathrm{CaCl}_{2}$ solution (Betelgeux S.A., Gandía, Valencia, Spain), 10 ppm of Mesófilo Plus Starter (Abiasa, Tui, Spain), 25 ppm of Lysozyme and 20 ppm of rennet (>92\% by mass of chimosin, Tecnilac, Mundão, Portugal) at $33{ }^{\circ} \mathrm{C}$. After production, whey was filtered, analysed and processed. The production of liquid whey protein concentrates (Fig. 1) consisted of whey concentration at $45-50{ }^{\circ} \mathrm{C}$ in a batch ultrafiltration pilot plant (Proquiga, Biotech S.A., La Coruña, Spain), using an organic polyvinylidene fluoride membrane UF 3838, with 10-kDa cut-off (Iberlact, Madrid, Spain), aiming for a volumetric concentration factor (volume feed/volume retentate) of 15. After ultrafiltration, the concentrate was thermally treated (at $90-95{ }^{\circ} \mathrm{C}$ for 5 min) under batch conditions in order to denature whey proteins. The heat treatment also pasteurized the product. The mixture was then homogenized at $10 \mathrm{MPa}$ using a homogenizer Rannie ${ }^{\mathrm{TM}}$ model Bluetop (Copenhagen, Denmark) to achieve a particle diameter of whey protein aggregates lower than $10 \mu \mathrm{m}$ to avoid graininess and increase smoothness of the concentrate. The ultrafiltrated permeate was concentrated by reverse osmosis using a pilot module (ORM - Tecnologia e Ciência na Indústria Lda, Belas, Portugal) equipped with a membrane model 2.5 S Seawater (Advanced Structures Inc., Los Angeles, CA, USA) aiming at a volumetric concentration factor of 2 , in order to obtain the concentrated ultrafiltration permeate, which was subsequently pasteurized under the

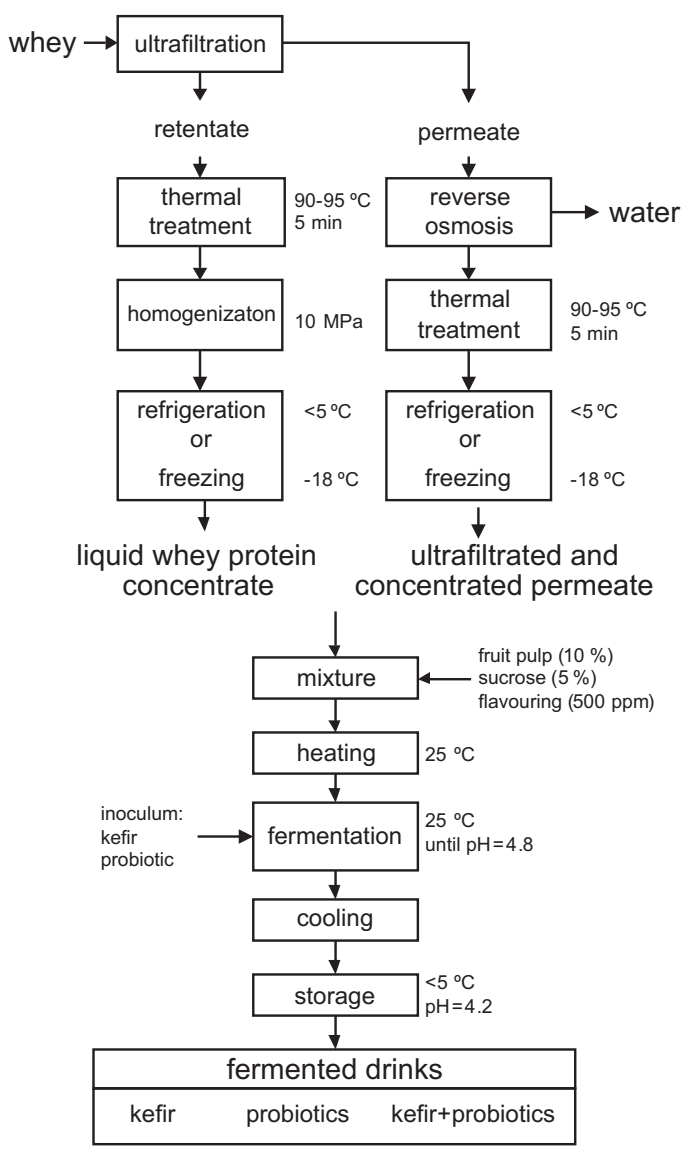

Fig. 1. Process diagram for the production of fermented drinks from whey 
same conditions as the liquid whey protein concentrates. After processing, both liquid whey protein concentrates and concentrated ultrafiltrated permeates were refrigerated $\left(<5^{\circ} \mathrm{C}\right)$ or frozen $\left(-18^{\circ} \mathrm{C}\right)$ for further utilization.

\section{Production of fermented drinks}

Liquid whey protein concentrates or concentrated ultrafiltrated permeates (fresh or thawed) were used as culture media for the production of fermented drinks. Mango fruit pulp (10\%, by mass; Continente, Coimbra, Portugal), sucrose (5\%, by mass) and mango flavouring (500 ppm; Aromas \& Sabores, Póvoa de Santo Adrião, Portugal) were added to liquid whey protein concentrates and concentrated ultrafiltrated permeates and the mixtures were acclimated at $25{ }^{\circ} \mathrm{C}$ before the addition of the inoculum. Three types of inocula were used: (i) fresh or thawed kefir grains CIDCA AGK1 (2.5\%, by mass per volume; Centro de Investigación y Desarollo en Criotecnología de Alimentos, La Plata, Argentina), (ii) a commercial mix of probiotic bacteria containing Lactobacillus acidophilus, Lactobacillus casei and Lactobacillus rhamnosus in a ratio of 1:1:1 (0.3 \%, by mass per volume; Sacco ${ }^{\mathrm{TM}}$, Lyofast ACR, Milan, Italy), and (iii) a mixture of (i) and (ii) in a 1:1 ratio.

The kefir grains used as inoculum for the production of fermented drinks were added, either fresh (incubated overnight at $25{ }^{\circ} \mathrm{C}$ in milk as culture media), or after thawing frozen grains. In both cases, the kefir grains were added to the formulations into a mesh bag during the fermentation period and removed before storage.

The inoculated liquid whey protein concentrates and concentrated ultrafiltrated permeates were incubated at $25{ }^{\circ} \mathrm{C}$ for $24 \mathrm{~h}$. Subsequently, the products were refrigerated to below $5{ }^{\circ} \mathrm{C}$ and kept under these conditions for 14 days. Fig. 1 presents the production process diagram of the fermented drinks.

\section{Physicochemical analyses}

The $\mathrm{pH}$, titratable acidity, and the content of total solids, ash and total proteins of dairy products were determined according to the Official Methods of Analysis (21). The $\mathrm{pH}$ was determined directly with a $\mathrm{pH}$ meter (HI 9025; HANNA Instruments, Ronchi di Villafranca, Padova, Italy). Titratable acidity, expressed as a percentage of lactic acid, was determined after titration using $0.1 \mathrm{M}$ $\mathrm{NaOH}$ solution. Total solids were determined after oven drying the samples at $105^{\circ} \mathrm{C}$. Ash content was obtained by incineration of dry samples in an electric muffle furnace (model LE 4/11/R6; Nabertherm, Lilienthal, Germany). Total nitrogen content was determined using the Kjeldahl method (21). Total protein content was estimated by multiplying the total nitrogen content of the samples by a factor of 6.38 . The fat content of liquid whey protein concentrate and concentrated ultrafiltrated permeate products was determined by the Gerber method (22). Each product sample was collected using the Portuguese specific standard procedure for dairy products (23).

Viscosity was evaluated with a Brookfield ${ }^{\mathrm{TM}}$ viscometer (Brookfield Engineering Laboratories, Madison, WI, USA) and expressed in mPa.s. Viscosity measurements of drinks with liquid whey protein concentrates were made at $8{ }^{\circ} \mathrm{C}$ and $1 \mathrm{rpm}$ for $30 \mathrm{~s}$ with spindle 01 and of drinks with concentrated ultrafiltrated permeates with the device UL Adapter (Brookfield Engineering Laboratories) at $100 \mathrm{rpm}$.

\section{Microbiological analysis}

Enumeration of viable microorganisms was carried out immediately after inoculation (at $0 \mathrm{~h}$ ), during the fermentation period (at 12 and $24 \mathrm{~h}$ ) and during refrigerated storage at $5{ }^{\circ} \mathrm{C}$ (at 48,168 and $336 \mathrm{~h}$ ). Counts of presumptive lactococci and lactobacilli were carried out on M17 agar BK088 and on MRS agar BK089 (Biokar Diagnostics, Beauvais, France), respectively, after aerobic incubation at $37{ }^{\circ} \mathrm{C}$ for $48 \mathrm{~h}$, according to the standard method specifications (24). Yeasts were enumerated on Rose Bengal chloramphenicol agar BK151 (Biokar Diagnostics) after incubation at $25^{\circ} \mathrm{C}$ for $72 \mathrm{~h}$.

\section{Sensorial analysis}

Consumer preference tests were performed with a panel of 35 persons with experience in sensorial evaluation. Products were tested on the 7th day of storage and panellists were asked to grade the different products on a scale from 1 (dislike) to 5 (like a lot). The sensory acceptability of the products was evaluated by a group of six trained members of the staff on an unacceptable/acceptable basis on the 14th day of storage.

\section{Statistical analysis}

Experiments were done in duplicate using three independent cultures of bacteria in each experiment. Analysis of variance (ANOVA) corresponding to the different assays was carried out using the software STATISTICA v. 8 (StatSoft Inc., Tulsa, OK, USA) (25). Comparison of mean values by Tukey's method was performed, and if $\mathrm{p}<0.05$, the differences were considered statistically significant.

\section{Results and Discussion}

\section{Chemical composition of fermented drinks}

Membrane technologies applied to cheese whey allowed for the production of a protein-enriched fraction and a lactose-enriched fraction. The use of such fractions as substrates for the production of fermented drinks as carried out in this work can be a reasonable alternative for in-plant valorization of cheese whey.

Table 1 shows the chemical composition of the fermented drinks. As expected, the levels of total solids, proteins and fat are higher in products based on liquid whey protein concentrates than in those obtained with concentrated ultrafiltrated permeates, in which lactose is the main solid component (approx. $80 \%$ of total solids). The presence of proteins and fat in concentrated ultrafiltrated permeates results from the permeate concentration by reverse osmosis, which doubled the residual levels of these components in the ultrafiltrated permeate, as well as from the low levels of proteins and fat in the added fruit pulp (approx. $1 \%$, by mass). 
Table 1. Overall chemical composition of fermented products obtained by inoculation of liquid whey protein concentrates and ultrafiltrated and concentrated permeates with kefir grains, commercial mix of probiotics, and kefir grains combined with commercial mix of probiotic

\begin{tabular}{ccccc}
\hline \multirow{2}{*}{ Product } & \multicolumn{5}{c}{$w / \%$} \\
\cline { 2 - 5 } & Total solids & Proteins & Fat & Ash \\
\hline LWPC & & & & \\
k & $(15.59 \pm 0.02)^{\mathrm{c}}$ & $(6.9 \pm 0.8)^{\mathrm{b}}$ & $(2.3 \pm 0.1)^{\mathrm{d}}$ & $(1.4 \pm 0.2)^{\mathrm{b}}$ \\
p & $(16.8 \pm 0.4)^{\mathrm{d}}$ & $(6.7 \pm 0.3)^{\mathrm{b}}$ & $(1.4 \pm 0.0)^{\mathrm{b}}$ & $(1.6 \pm 0.1)^{\mathrm{b}}$ \\
k+p & $(16.70 \pm 0.04)^{\mathrm{d}}$ & $(6.37 \pm 0.09)^{\mathrm{b}}$ & $(1.7 \pm 0.1)^{\mathrm{c}}$ & $(1.60 \pm 0.05)^{\mathrm{b}}$ \\
\hline UFCP & & & & \\
k & $(11.5 \pm 0.2)^{\mathrm{b}}$ & $(0.50 \pm 0.03)^{\mathrm{a}}$ & $(0.4 \pm 0.1)^{\mathrm{a}}$ & $(1.16 \pm 0.01)^{\mathrm{a}}$ \\
p & $(10.84 \pm 0.05)^{\mathrm{a}}$ & $(0.78 \pm 0.07)^{\mathrm{a}}$ & $(0.37 \pm 0.06)^{\mathrm{a}}$ & $(1.07 \pm 0.01)^{\mathrm{a}}$ \\
k+p & $(11.27 \pm 0.07)^{\mathrm{b}}$ & $(0.62 \pm 0.07)^{\mathrm{a}}$ & $(0.37 \pm 0.06)^{\mathrm{a}}$ & $(1.12 \pm 0.01)^{\mathrm{a}}$ \\
\hline
\end{tabular}

Different letters in superscript indicate statistically significant differences $(p<0.05)$. LWPC=liquid whey protein concentrate, $\mathrm{UFCP}=$ ultrafiltrated and concentrated permeate, $\mathrm{k}=\mathrm{kefir}$ grains, $\mathrm{p}=$ commercial mix of probiotics, $\mathrm{k}+\mathrm{p}=\mathrm{kefir}$ grains with commercial mix of probiotics

\section{$\mathrm{pH}$ and acidity during fermentation and storage}

Table 2 shows the changes in the $\mathrm{pH}$ and titratable acidity values of the products during fermentation (at 0 and $24 \mathrm{~h}$ ) and after 7 days of storage (at $168 \mathrm{~h}$ ). Products with liquid whey protein concentrates had an initial $\mathrm{pH}$ in the range of 5.37-5.50, and after fermentation the $\mathrm{pH}$ was reduced to values lower than 4.5. During refrigerated storage, these values decreased to $4.2-4.3$. In these products the titratable acidity increased from approx. 0.039 to $0.077-0.087 \%$ of lactic acid. It can also be observed that the products with liquid whey protein concentrates containing the commercial probiotic cultures had lower acidity than the ones containing kefir grains or the mixture of kefir grains and commercial probiotic bacteria.

The initial $\mathrm{pH}$ of drinks with concentrated ultrafiltrated permeates was significantly lower than of products with liquid whey protein concentrates, most probably as a result of the absence of whey proteins that have a buffer capacity, and also of the acidification that occurred during the concentration by reverse osmosis $\left(18-25^{\circ} \mathrm{C}, 2 \mathrm{~h}\right)$.
These values decreased to less than 4.5 after fermentation $(t=24 \mathrm{~h})$, with the exception of the products containing the commercial probiotic mix, in which it did not change in the first $24 \mathrm{~h}$. This may be explained by the fact that the composition of these products does not favour the growth of the probiotic starter culture. However, after 7 days of storage, the $\mathrm{pH}$ of the products was similar to the ones obtained using kefir grains as inoculum. It appears that mixing of kefir grains with probiotic bacteria had a synergistic effect on the growth of both cultures (Table 2) at high lactose mass fractions such as in products with concentrated ultrafiltrated permeates. In these products, differences in acidity were not significant $(p>0.05)$. As it can be observed in Table 2, drinks with concentrated ultrafiltrated permeates had much lower acidity than those with liquid whey protein concentrates. Despite the high acidity developed in the latter, the $\mathrm{pH}$ remained in the range of $4.2-4.5$ as a result of the buffer effect of whey proteins.

\section{Viscosity of fermented drinks}

As expected, products with liquid whey protein concentrates had higher viscosity than the products with concentrated ultrafiltrated permeates (Table 3). This reflects the higher levels of solids, proteins and fat in the former. A significant $(\mathrm{p}<0.05)$ decrease of viscosity of drinks with liquid whey protein concentrates from day 1 to day 7 (at $168 \mathrm{~h}$ ) was observed especially when fermented with kefir grains. Viscosity of the products with concentrated ultrafiltrated permeates slightly increased during storage.

Due to their low molecular mass and spherical shape, native whey proteins are poor thickening agents. The thermal aggregation of whey proteins increases their hydrodynamic volumes, thus favouring their thickening properties. In this case, the thermal treatment of the liquid whey protein concentrates allowed for the formation of such aggregates, while the homogenization step eliminated graininess and increased smoothness, being determinant for the final viscosity of the product. Products containing liquid whey protein concentrates fermented with commercial probiotic bacteria or with the mixture of kefir grains and commercial probiotic bacteria had significantly higher viscosity than the ones containing just kefir

Table 2. The $\mathrm{pH}$ and titratable acidity during fermentation and storage of whey drinks produced using liquid whey protein concentrates and ultrafiltrated and concentrated permeates with kefir grains, commercial mix of probiotics, and kefir grains combined with commercial mix of probiotics

\begin{tabular}{|c|c|c|c|c|c|c|c|}
\hline \multirow{2}{*}{ Parameter } & \multirow{2}{*}{$t / h$} & \multicolumn{3}{|c|}{ LWPC } & \multicolumn{3}{|c|}{ UFCP } \\
\hline & & $\mathrm{k}$ & $\mathrm{p}$ & $\mathrm{k}+\mathrm{p}$ & $\mathrm{k}$ & $\mathrm{p}$ & $\mathrm{k}+\mathrm{p}$ \\
\hline \multirow{3}{*}{$\mathrm{pH}$} & 0 & $(5.5 \pm 0.1)^{c}$ & $(5.4 \pm 0.1)^{c}$ & $(5.37 \pm 0.06)^{c}$ & $(4.80 \pm 0.05)^{c}$ & $(4.80 \pm 0.04)^{\mathrm{c}}$ & $(4.79 \pm 0.01)^{c}$ \\
\hline & 24 & $(4.47 \pm 0.06)^{\mathrm{b}}$ & $(4.47 \pm 0.06)^{\mathrm{b}}$ & $(4.33 \pm 0.06)^{\mathrm{ab}}$ & $(4.43 \pm 0.06)^{\mathrm{b}}$ & $(4.7 \pm 0.1)^{c}$ & $(4.1 \pm 0.1)^{\mathrm{a}}$ \\
\hline & 168 & $(4.25 \pm 0.05)^{\mathrm{a}}$ & $(4.15 \pm 0.05)^{\mathrm{a}}$ & $(4.19 \pm 0.01)^{\mathrm{a}}$ & $(4.38 \pm 0.03)^{\mathrm{b}}$ & $(4.43 \pm 0.06)^{\mathrm{b}}$ & $(4.1 \pm 0.1)^{\mathrm{a}}$ \\
\hline \multirow{3}{*}{$\mathrm{TA} \cdot 10^{2} / \%$} & 0 & $(3.9 \pm 0.1)^{a}$ & $(4.00 \pm 0.06)^{\mathrm{a}}$ & $(3.97 \pm 0.08)^{\mathrm{a}}$ & $(0.73 \pm 0.03)^{\mathrm{a}}$ & $(0.73 \pm 0.03)^{a}$ & $(0.73 \pm 0.03)^{\mathrm{a}}$ \\
\hline & 24 & $(8.0 \pm 0.1)^{\mathrm{cd}}$ & $(6.9 \pm 0.2)^{\mathrm{b}}$ & $(8.6 \pm 0.3)^{\mathrm{e}}$ & $(3.2 \pm 0.5)^{\mathrm{bc}}$ & $(3.5 \pm 0.1)^{\mathrm{cd}}$ & $(2.96 \pm 0.04)^{b}$ \\
\hline & 168 & $(8.4 \pm 0.2)^{\mathrm{de}}$ & $(7.71 \pm 0.09)^{\mathrm{c}}$ & $(8.67 \pm 0.05)^{\mathrm{e}}$ & $(3.83 \pm 0.02)^{\mathrm{d}}$ & $(2.96 \pm 0.03)^{\mathrm{b}}$ & $(2.95 \pm 0.05)^{b}$ \\
\hline
\end{tabular}

Different letters in superscript indicate statistically significant differences $(p<0.05)$. LWPC=liquid whey protein concentrate,

$\mathrm{UFCP}=$ ultrafiltrated and concentrated permeate, $\mathrm{k}=\mathrm{kefir}$ grains, $\mathrm{p}=\mathrm{commercial}$ mix of probiotics, $\mathrm{k}+\mathrm{p}=\mathrm{kefir}$ grains with commercial mix of probiotics, TA=titratable acidity as percentage of lactic acid 
Table 3. Viscosity of the drinks obtained by fermentation of liquid whey protein concentrates and ultrafiltrated and concentrated permeates with kefir grains, commercial mix of probiotics, and kefir grains combined with commercial mix of probiotics

\begin{tabular}{crccc}
\hline Product & $t / h$ & $k$ & $p$ & $\frac{\mu /(\mathrm{mPa} \cdot \mathrm{s})}{\mathrm{k}+\mathrm{p}}$ \\
\hline \multirow{2}{*}{ LWPC } & 24 & $(3013.3 \pm 15.3)^{\mathrm{b}}$ & $(3650.0 \pm 217.0)^{\mathrm{d}}$ & $(3443.3 \pm 20.8)^{\mathrm{cd}}$ \\
& 168 & $(1816.7 \pm 15.3)^{\mathrm{a}}$ & $(3236.7 \pm 15.3)^{\mathrm{bc}}$ & $(3153.3 \pm 5.8)^{\mathrm{b}}$ \\
\hline \multirow{2}{*}{ UFCP } & 24 & $(2.30 \pm 0.01)^{\mathrm{a}}$ & $(2.43 \pm 0.01)^{\mathrm{c}}$ & $(2.35 \pm 0.01)^{\mathrm{b}}$ \\
& 168 & $(3.07 \pm 0.01)^{\mathrm{f}}$ & $(2.95 \pm 0.01)^{\mathrm{e}}$ & $(2.82 \pm 0.01)^{\mathrm{d}}$ \\
\hline
\end{tabular}

Different letters in superscript within the same base product indicate statistically significant differences $(\mathrm{p}<0.05)$.

LWPC=liquid whey protein concentrate, $\mathrm{UFCP}=$ ultrafiltrated and concentrated permeate, $k=$ kefir grains, $\mathrm{p}=$ commercial mix of probiotics, $\mathrm{k}+\mathrm{p}=\mathrm{kefir}$ grains with commercial mix of probiotics

grains. This fact can be explained by the lower solid contents of the latter (Table 1).

Viscosity of the products with liquid whey protein concentrates was almost three times higher than the ones reported for cow's and goat's milk yoghurts of approx. 3.4 $\%$ protein, in which polymerized whey proteins and pectin were used as gelling agents (7). This can be explained considering the high level of protein, which is nearly twice as high in products with liquid whey protein concentrates ( $>6 \%$ protein). The viscosity of products with liquid whey protein concentrates is $2-3$ times lower than the one reported for yoghurts in which different commercial whey protein concentrates were used to enrich the protein content of milk up to $4.5 \%$ (by mass) (26), but it is of the same order of magnitude as the one obtained for low-fat yoghurts, in which microparticulated whey proteins were used as fat replacers, and with protein levels between 4.25 and $5.0 \%$ (by mass) (12).

\section{Microbiological profile of fermented products}

Concerning microbial enumeration (Fig. 2), it was observed that freezing and then thawing kefir inoculum negatively affected the counts of lactobacilli, lactococci and yeasts in drinks with liquid whey protein concentrates and concentrated ultrafiltrated permeates (Figs. 2c and d). As expected, when thawed kefir grains were used, microbial counts were in the order of $2 \log$ below the ones observed in products obtained after inoculation with fresh kefir grains (Figs. 2a and b). It is therefore concluded that freezing and thawing the inoculum is a harmful process for microorganisms, and if kefir grains are to be kept frozen for storage, they require a prior activation at $25^{\circ} \mathrm{C}$ for $24 \mathrm{~h}$ before inoculating the products.

On the other hand, as it can be observed in Fig. 3, freezing liquid whey protein concentrates and keeping them frozen for one month did not affect its ability as culture medium to produce fermented drinks with kefir grains, commercial probiotic bacteria, or both. Hence, this procedure may be used to preserve liquid whey protein concentrates in small/medium size dairy factories which do not possess evaporation/drying equipment.
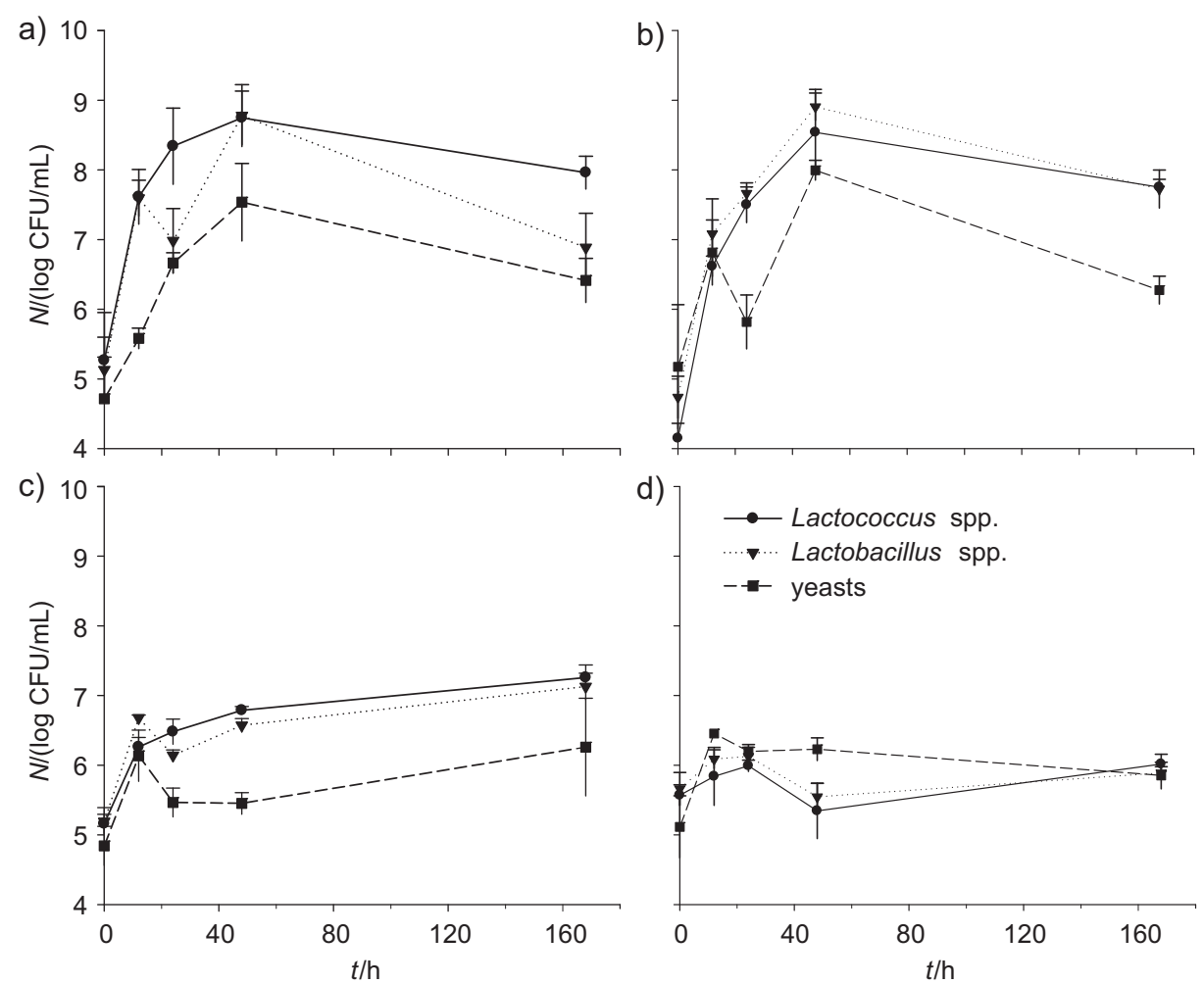

Fig. 2. Microbiological profile of the fermented drinks: a) liquid whey protein concentrates fermented with fresh kefir grain inoculum, b) concentrated ultrafiltrated permeates with fresh kefir grain inoculum, c) liquid whey protein concentrates with thawed kefir grain inoculum, d) concentrated ultrafiltrated permeates with thawed kefir grain inoculum. Fresh kefir grains were obtained by overnight fermentation of milk at $25^{\circ} \mathrm{C}$ and thawed kefir grains were added after thawing frozen kefir grains previously prepared under the same conditions 
The number of yeasts was above $6 \log \mathrm{CFU} / \mathrm{mL}$, except for the products with solely commercial probiotic bacteria. Counts of lactococci and lactobacilli were above $7 \log \mathrm{CFU} / \mathrm{mL}$ in all the fermented drinks (Fig. 3), being similar to those reported for yoghurts produced with milk (12\% of total solids) and milk and whey bases ( 8 and $10 \%$ of total solids) (27) or to whey-based fermented beverages (28). The highest microbial counts of lactobacilli and lactococci were observed in products containing the mixture of kefir grains and probiotic bacteria (Figs. 3e and $\mathrm{f})$, which is consistent with the values obtained for lactic acid production (Table 2). Microbial counts of viable lactobacilli, lactococci and yeasts were still high after 14 days of storage, showing the resistance of the strains towards storage conditions. It has been reported that the benefits of probiotic consumption can be obtained when the food products contain at least $6-7 \log \mathrm{CFU} / \mathrm{mL}$ of viable microorganisms per $\mathrm{g}$ of product at the end of shelf life $(29,30)$. The probiotic properties of kefir microorgan- isms are well known (16-20), and fermented drinks are usually consumed within 15 days of storage. Therefore, the use of fresh kefir grains and/or commercial probiotics as inocula of liquid whey protein concentrates or concentrated ultrafiltrated permeates appears as an excellent choice for the production of functional fermented drinks.

If particular probiotic bacteria are used in combination with kefir microorganisms in fermented drinks based on liquid whey protein concentrates, most of the $\beta$-lactoglobulin and lactose can be removed, reducing to a minimum the potential allergenicity or lactose intolerance of such products, which have high concentrations of essential and sulphur-containing amino acids $(28,31)$.

\section{Sensory evaluation}

Fermented drinks with liquid whey protein concentrates obtained using kefir grains or the mixture of kefir grains and commercial probiotic bacteria as inocula re-
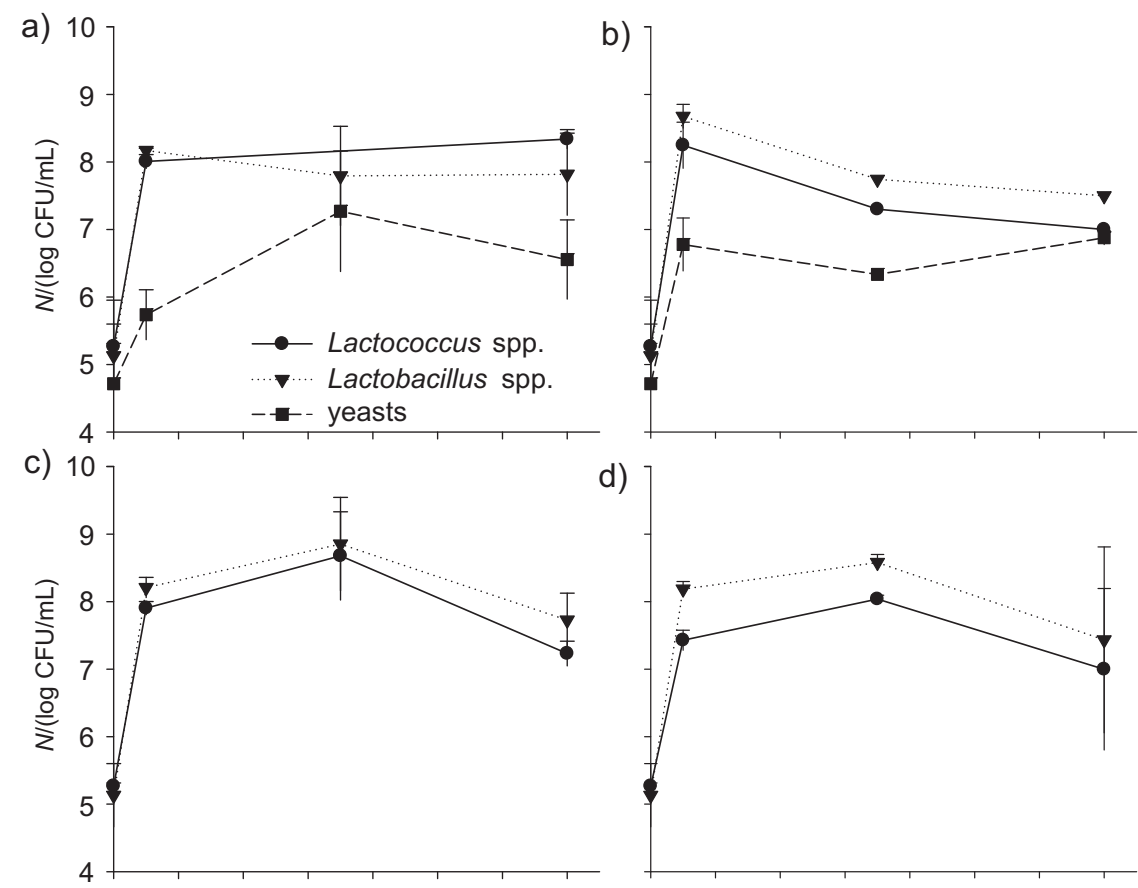

d)
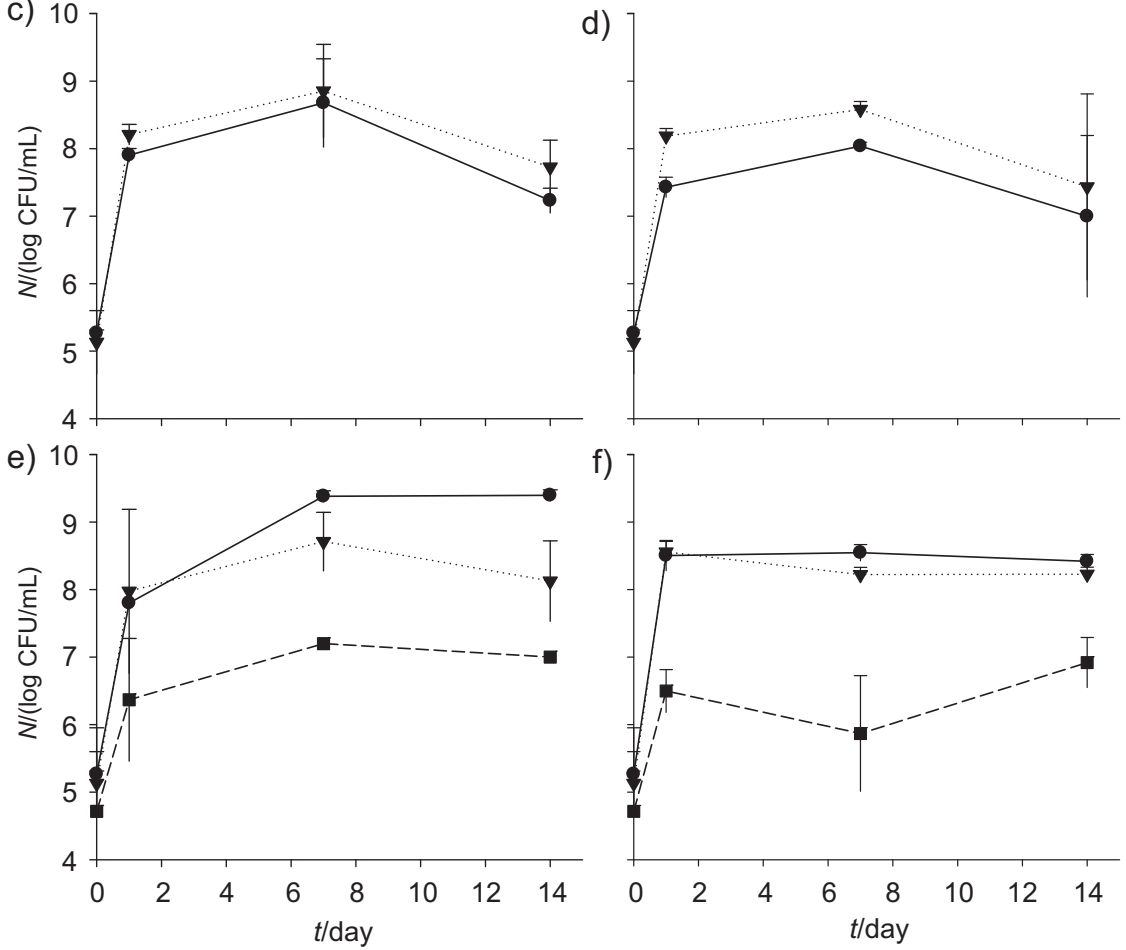

Fig. 3. Microbiological profile of the fermented drinks produced from liquid whey protein concentrates: a) kefir with fresh liquid whey protein concentrates, b) kefir with thawed liquid whey protein concentrates, c) commercial mix of probiotics with fresh liquid whey protein concentrates, d) commercial mix of probiotics with thawed liquid whey protein concentrates, e) kefir combined with commercial mix of probiotics with fresh liquid whey protein concentrates, f) kefir combined with commercial mix of probiotics with thawed liquid whey protein concentrates 
ceived better scores in sensory evaluation (Fig. 4). Indeed, almost $60 \%$ of the consumers gave them 4 or 5 points (on a five-grade scale). Products with concentrated ultrafiltrated permeates were less appreciated, as less than $25 \%$ of consumers gave them 4 or more points (Fig. 5).

Among products with liquid whey protein concentrates, preferred was the one fermented with kefir grains, while among products with concentrated ultrafiltrated permeates the one fermented with the commercial probiotic culture received the highest score. Consumers referred that products with liquid whey protein concentrates had the characteristics of yoghurt but with a palatable carbonated taste associated with gas production by kefir microorganisms. A general comment about products with concentrated ultrafiltared permeates was that they did not have the typical characteristics of a dairy

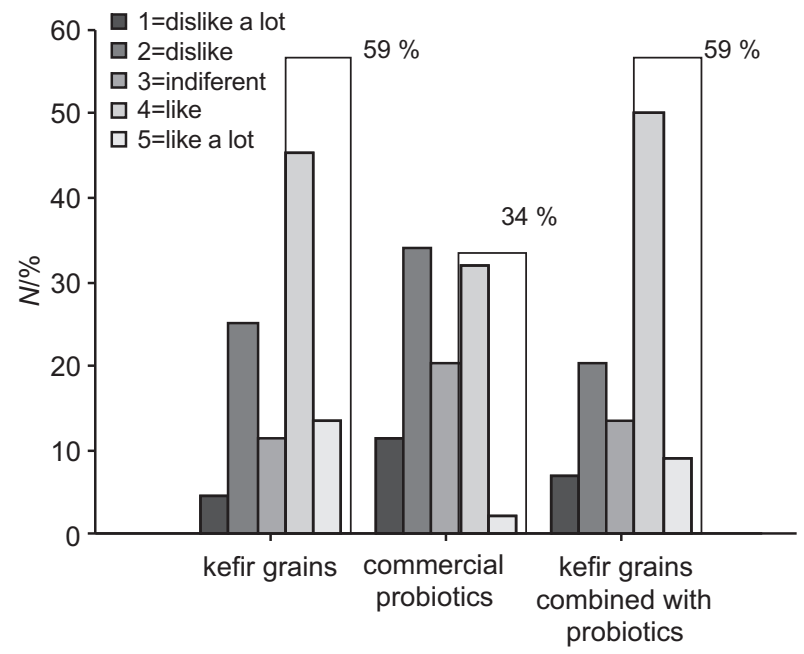

Fig. 4. Sensory evaluation of fermented drinks produced from liquid whey protein concentrates. Number of the consumers that classified products in the indicated range is expressed in percentage

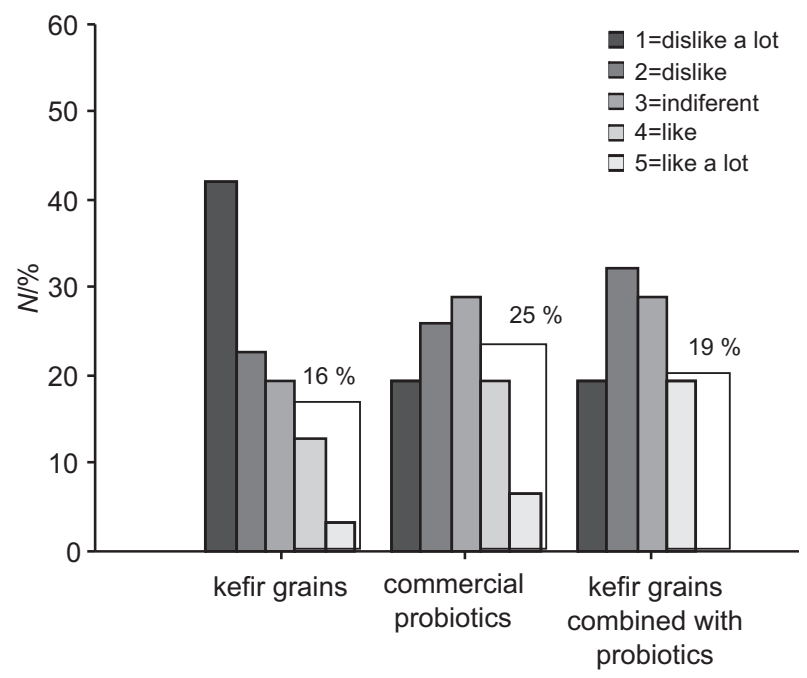

Fig. 5. Sensory evaluation of fermented drinks produced from concentrated ultrafiltrated permeates. Number of the consumers that classified products in the indicated range is expressed in percentage product, being associated with low quality fruit juices. After 14 days of storage the products still kept acceptable sensory characteristics when evaluated by an experienced panel. Further work is needed in the development of these products in order to introduce different fruits and to improve the consumer acceptability of the products. In the developed products, the use of fruit pulp masked the possible development of turbidity during their shelf life. If the intention is to produce the same type of fermented drinks without fruit pulp this aspect should be endorsed.

\section{Conclusion}

The impact of this work comes from two main aspects: (i) the use of liquid whey protein concentrates and ultrafiltrated and concentrated permeates, and (ii) the production of palatable fermented drinks. It must be underlined that obtaining liquid whey protein concentrates and ultrafiltrated and concentrated permeates resulted in the complete use of whey, that is, only water remained as whey by-product. From this perspective, the use of liquid whey protein concentrates and ultrafiltrated and concentrated permeates certainly contributes to the protection of environment. This strategy may also be extremely attractive for medium/small producers, who intend to develop integrated solutions for the cheese whey problem by viewing its great potential as a source of added value to incorporate into own products.

On the other hand, the counts of probiotic microorganisms after 14 days of storage at refrigeration temperatures are compatible with those required by international organisations like EFSA or FDA to provide the benefits of consuming probiotics.

On the whole, the strategy developed in this work can be considered a valuable contribution to expand the applications of products derived from whey fractionation in medium/small cheese industries for the design of new functional foods.

\section{Acknowledgements}

This work was supported by CERNAS - Research Center for Natural Resources, Environment and Society, Coimbra, Portugal, and CYTED Program (108RT0362; 312RT0463). AGZ and GDA are members of the Research Career from the Argentinean National Research Council (CONICET) and the Commission for Scientific Research (CIC-PBA), respectively.

\section{References}

1. Blaskó B. World importance and present tendencies of dairy sector. Applied Studies in Agribusiness and Commerce APSTRACT. Budapest, Hungary: Agroinform Publishing House; 2012. pp.119-23.

http://ageconsearch.umn.edu/bitstream/104683/2/20_Blasko_PHD_Apstract.pdf

2. Global opportunities for whey and lactose ingredients 2010 2014. 3ABC - 3A Business Consulting.

http://www.3abc.dk/Report\%20information\%20-\%20Global $\% 20$ Opportunities\%20for\%20Whey\%20and\%20Lactose \% 20Ingredients\%202010-2014.pdf

3. Singer NS, Yamamoto S, Latella J. Protein product base. European patent EP 0250623 B1. 1990. 
4. Torres IC, Rubio JMA, Ipsen R. Using fractal image analysis to characterize microstructure of low-fat stirred yoghurt manufactured with microparticulated whey protein. J Food Eng. 2012;109:721-9. http://dx.doi.org/10.1016/j.jfoodeng.2011.11.016

5. Vardhanabhuti B, Foegeding EA. Rheological properties and characterization of polymerized whey protein isolates. J Agric Food Chem. 1999;47:3649-55. http://dx.doi.org/10.1021/jf981376n

6. Vardhanabhuti B, Foegeding EA, McGuffey MK, Daubert $\mathrm{CR}$, Swaisgood HE. Gelation properties of dispersions containing polymerized and native whey protein isolate. Food Hydrocolloid. 2001;15:165-75. http://dx.doi.org/10.1016/S0268-005X(00)00062-X

7. Wang W, Bao Y, Hendricks GM, Guo M. Consistency, microstructure and probiotic survivability of goats' milk yoghurt using polymerized whey protein as a co-thickening agent. Int Dairy J. 2012;24:113-9. http://dx.doi.org/10.1016/j.idairyj.2011.09.007

8. Nicolai T, Britten M, Schmitt C. $\beta$-Lactoglobulin and WPI aggregates: formation, structure and applications. Food Hydrocolloid. 2011;25:1945-62.

http://dx.doi.org/10.1016/j.foodhyd.2011.02.006

9. Antunes AC, Cazetto TF, Bolini HLA. Viability of probiotic micro-organisms during storage, postacidification and sensory analysis of fat-free yogurts with added whey protein concentrate. Int J Dairy Technol. 2005;58:169-73. http://dx.doi.org/10.1111/j.1471-0307.2005.00203.x

10. Amatayakul T, Sherkat, Shah NP. Syneresis in set yogurt as affected by EPS starter cultures and levels of solids. Int J Dairy Technol. 2006;59:216-21. http://dx.doi.org/10.1111/j.1471-0307.2006.00264.x

11. Sodini I, Mattas J, Tong PS. Influence of $\mathrm{pH}$ and heat treatment of whey on the functional properties of whey protein concentrates in yoghurt. Int Dairy J. 2006;16:1464-9. http://dx.doi.org/10.1016/j.idairyj.2005.03.014

12. Torres IC, Janhøj T, Mikkelsen BØ, Ipsen R. Effect of microparticulated whey protein with varying content of denatured protein on the rheological and sensory characteristics of low-fat yoghurt. Int Dairy J. 2011;21:645-55.

http://dx.doi.org/10.1016/j.idairyj.2010.12.013

13. Henriques MHF, Gomes DMGS, Rodrigues D, Pereira CJD, Gil MHM. Performance of bovine and ovine liquid whey protein concentrate on functional properties of set yoghurts. Procedia Food Sci. 2011;1:2007-14.

http://dx.doi.org/10.1016/j.profoo.2011.10.001

14. Henriques MHF, Gomes DMGS, Pereira CJD, Gil MHM. Effects of liquid whey protein concentrate on functional and sensorial properties of set yogurts and fresh cheese. Food Bioprocess Tech. 2013;6:1-12.

http://dx.doi.org/10.1007/s11947-012-0778-9

15. Abraham A, Gómez-Zavaglia A, Garrote G, Brandi LI, De Antoni GL, Fausto R. Fermented product based on milk whey permeate: production processes and uses. International patent WO 2011005128 A2. 2011.

16. Londero A, Hamet MF, De Antoni GL, Garrote GL, Abraham AG. Kefir grains as a starter for whey fermentation at different temperatures: chemical and microbiological characterization. J Dairy Res. 2012;79:262-71. http://dx.doi.org/10.1017/S0022029912000179

17. Bolla PA, de Los Angeles Serradell M, de Urraza PJ, De Antoni GL. Effect of freeze-drying on viability and in vitro pro- biotic properties of a mixture of lactic acid bacteria and yeasts isolated from kefir. J Dairy Res. 2011;78:15-22. http://dx.doi.org/10.1017/S0022029910000610

18. Bolla PA, Carasi P, Bolla MLA, De Antoni GL, Serradell MLA. Protective effect of a mixture of kefir-isolated lactic acid bacteria and yeasts in a hamster model of Clostridium difficile infection. Anaerobe. 2013;21:28-33.

http://dx.doi.org/10.1016/j.anaerobe.2013.03.010

19. Franco MC, Golowczyc MA, De Antoni GL, Pérez PF, Humen M, Serradell MLA. Administration of kefir-fermented milk protects mice against Giardia intestinalis infection. J Med Microbiol. 2013;62:1815-22. http://dx.doi.org/10.1099/jmm.0.068064-0

20. Golowczyc MA, Mobili P, Garrote GL, Abraham AG, De Antoni GL. Protective action of Lactobacillus kefir carrying Slayer protein against Salmonella enterica serovar Enteritidis. Int J Food Microbiol. 2007;118:264-73. http://dx.doi.org/10.1016/j.ijfoodmicro.2007.07.042

21. Dairy products. Official Methods of Analysis, Vol. II. Arlington, TX, USA: Association of Official Analytical Chemists; 1995.

22. Milk and dairy products. Portuguese standards. Lisboa, Portugal: IPQ - Portuguese Institute of Quality; 1990 (in Portuguese).

23. NP 4146. Milk and dairy products. Methods for collecting samples. Technical Commission - 32. Lisbon, Portugal: IPQ - Portuguese Institute of Quality; 1991 (in Portuguese).

24. ISO 20128:2005. Milk products - Enumeration of presumptive lactobacillus acidophilus on a selective medium - Colony - count technique at $37^{\circ} \mathrm{C}$. Geneva, Switzerland: International Organization for Standardization (ISO); 2005.

25. STATISTICA (Data Analysis Software System), v. 12, StatSoft, Inc, Tulsa, OK, USA; 2013. http://www.statsoft.com.

26. Sodini I, Montella J, Tong PS. Physical properties of yogurt fortified with various commercial whey protein concentrates. J Sci Food Agr. 2005;85:853-9. http://dx.doi.org/10.1002/jsfa.2037

27. Almeida KE, Tamime AY, Oliveira MN. Influence of total solids contents of milk whey on the acidifying profile and viability of various lactic acid bacteria. LWT - Food Sci Technol. 2009;42:672-8. http://dx.doi.org/10.1016/j.lwt.2008.03.013

28. Pescuma M, Hebert EM, Mozzi F, Font de Valdez G. Functional fermented whey-based beverage using lactic acid bacteria. Int J Food Microbiol. 2010;141:73-81. http://dx.doi.org/10.1016/j.ijfoodmicro.2010.04.011

29. Tripathi MK, Giri SK. Probiotic functional foods: survival of probiotics during processing and storage. J Funct Food. 2014;9:225-41. http://dx.doi.org/10.1016/j.jff.2014.04.030

30. Hill C, Guarner F, Reid G, Gibson GR, Merenstein DJ, Pot B, et al. The International Scientific Association for Probiotics and Prebiotics consensus statement on the scope and appropriate use of the term probiotic. Nat Rev Gastroenterol Hepatol. 2014;11:506-14.

http://dx.doi.org/10.1038/nrgastro.2014.66

31. Smithers GW. Whey and whey proteins - from 'gutter-to-gold'. Int Dairy J. 2008;18:695-704. http://dx.doi.org/10.1016/j.idairyj.2010.12.013 